
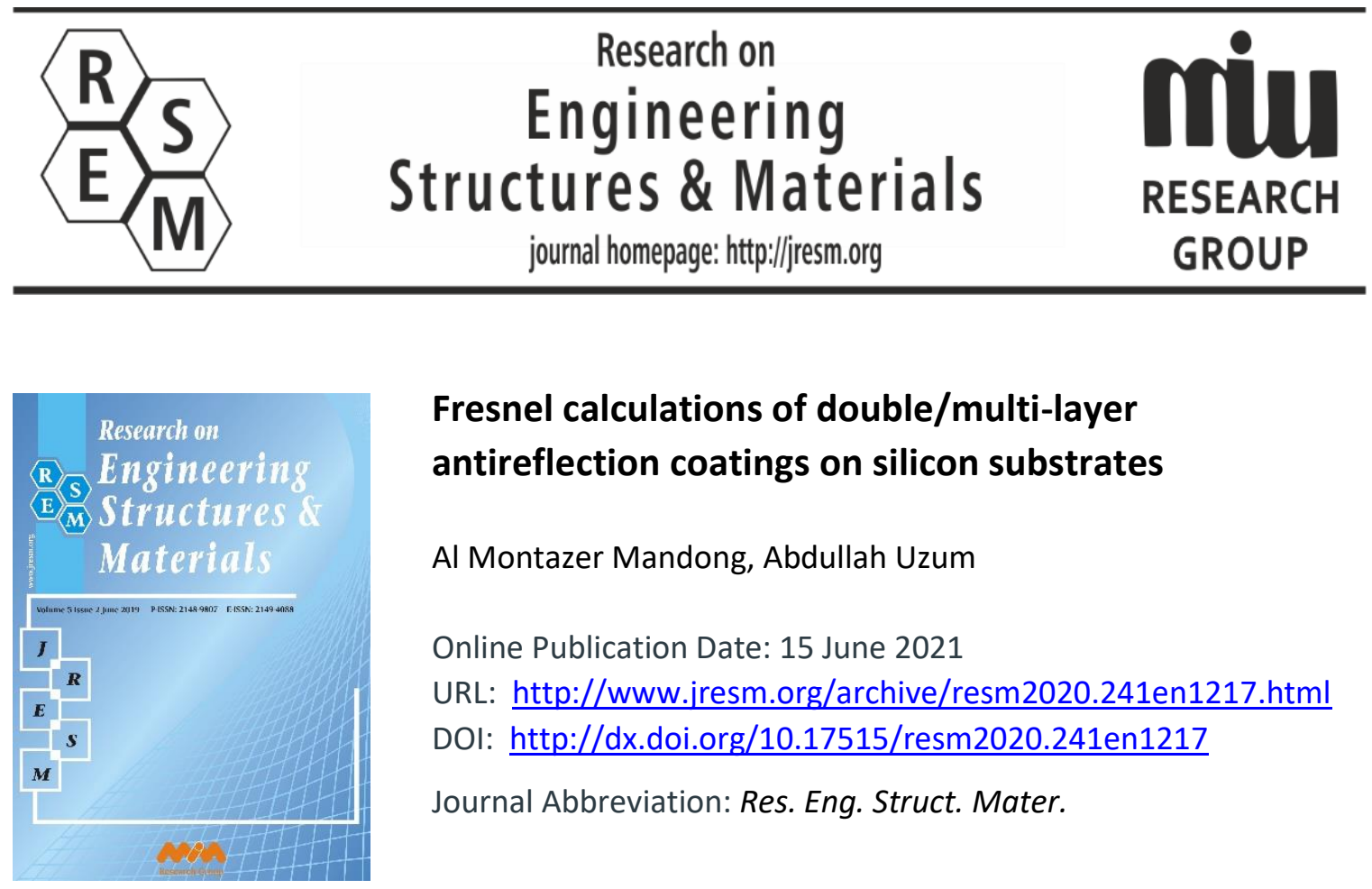

\title{
Fresnel calculations of double/multi-layer antireflection coatings on silicon substrates
}

Al Montazer Mandong, Abdullah Uzum

Online Publication Date: 15 June 2021

URL: http://www.jresm.org/archive/resm2020.241en1217.html

DOI: http://dx.doi.org/10.17515/resm2020.241en1217

Journal Abbreviation: Res. Eng. Struct. Mater.

\section{To cite this article}

Mandong AM, Uzum A. Fresnel calculations of double/multi-layer antireflection coatings on silicon substrates. Res. Eng. Struct. Mater., 2021; 7(4): 539-550.

\section{Disclaimer}

All the opinions and statements expressed in the papers are on the responsibility of author(s) and are not to be regarded as those of the journal of Research on Engineering Structures and Materials (RESM) organization or related parties. The publishers make no warranty, explicit or implied, or make any representation with respect to the contents of any article will be complete or accurate or up to date. The accuracy of any instructions, equations, or other information should be independently verified. The publisher and related parties shall not be liable for any loss, actions, claims, proceedings, demand or costs or damages whatsoever or howsoever caused arising directly or indirectly in connection with use of the information given in the journal or related means.

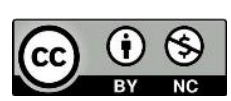

Published articles are freely available to users under the terms of Creative Commons Attribution - NonCommercial 4.0 International Public License, as currently displayed at here (the "CC BY - NC"). 


\title{
Research on Engineering Structures \& Materials
}

journal homepage: http://jresm.org

Research Article

\section{Fresnel calculations of double/multi-layer antireflection coatings on silicon substrates}

\author{
Al Montazer Mandong1,a, Abdullah Uzum*1,2,b \\ ${ }^{1}$ Department of Electrical and Electronics Engineering, Karadeniz Technical University, Trabzon, Turkey \\ ${ }^{2}$ Department of Renewable Energy Resources/Technologies, Karadeniz Technical University, Trabzon, Turkey

Article Info Abstract \\ Article history: \\ Received 17 Dec 2020 \\ Revised 25 May 2021 \\ Accepted 14 Jun 2021 \\ Keywords: \\ Solar cells; \\ Fresnel equations; \\ Antireflection coating; \\ Reflectance spectra calculations of double and multi-layer antireflection coating \\ (ARC) structures based on Fresnel equations were studied in this work. A \\ detailed explanation of Fresnel equations was presented with different \\ polarization of incoming light for multi-layer antireflection coatings for solar cell \\ applications. $\mathrm{TiO}_{2} / \mathrm{SiN}_{\mathrm{x}}, \mathrm{MgF}_{2} / \mathrm{ZnS}$ thin film stacks for double layer ARC and \\ $\mathrm{SiO}_{2} / \mathrm{Al}_{2} \mathrm{O}_{3} / \mathrm{TiO}_{2}, \mathrm{MgF}_{2} / \mathrm{SiO}_{2} / \mathrm{TiO}_{2}$ thin film stacks for multi-layer ARC were \\ studied. Transfer matrix method and PC1D simulation software were used \\ additionally to simulate crystalline silicon solar cells with considered double and \\ multi-layer ARC films on their front surface with calculated thicknesses. Average \\ reflectance (400-1100 $\mathrm{nm}$ ) of silicon surface by Fresnel equations with triple \\ layer ARC was around $2.72 \%$. Solar cell performances with each ARC structure \\ were compared to evaluate the achieved output of reflectance of investigated \\ thin films. Simulated short circuit current density of solar cells with tri-layer ARC \\ was $39.71 \mathrm{~mA} / \mathrm{cm}^{2}$, was significantly higher than that of the ARC-free solar cells \\ resulting in an efficiency of $19.1 \%$.
}

(C) 2021 MIM Research Group. All rights reserved.

\section{Introduction}

Solar cell industry is dominated by crystalline silicon solar cells with a global market share of $93 \%$ [1]. The highest confirmed efficiency for monocrystalline and multicrystalline are $26.7 \%$ and $22.3 \%$ respectively $[1,2]$. Achieving high efficiencies with low cost is important to expand the use of solar energy based on photovoltaics. To establish high efficiencies of solar cells, numerous researchers and scientists have been looking for various ways in utilizing the basic techniques to improve the efficiency of solar cells. One the most important part of the production of modern high-efficiency solar cell is the integration of antireflection coating [3]. Antireflection coating (ARC) is a thin film layer of dielectric material deposited on top of the surface of solar cell to reduce optical losses due to reflection and increase the transmittance of light, thus improving current generation of solar cell and improve its overall efficiency. Silicon nitride is the most widely used antireflection coating in industrial level production of solar cells due to various advantages such as bulk and surface passivation properties and proven stability [4,5]. As a result, deposition of $\mathrm{SiN}_{\mathrm{x}}$ using plasma enhanced chemical vapor deposition (PECVD) became an integral part in the production of modern silicon solar cells $[4,6]$. Other than that, alternative ARCs including $\mathrm{TiO}_{2}, \mathrm{SiO}_{2}, \mathrm{Al}_{2} \mathrm{O}_{3}, \mathrm{ZrO}_{2}, \mathrm{HfO}_{2}$ etc. has been studied and applied to the solar cell structures by a variety of deposition techniques both as a single layer or as in stacks [3,7-11]. On the other hand, solar cell simulation softwares support researchers to design, develop and optimize solar cells. Softwares such as Silvaco TCAD, Sentaurus TCAD and PC1D are used to study the significance of antireflection coating in improving the efficiency of solar cells [12-14]. Lenie et. al demonstrated the effect of $\mathrm{SiO}_{2}$ and $\mathrm{Si}_{3} \mathrm{~N}_{4}$ as

\footnotetext{
${ }^{*}$ Corresponding author: auzum@ktu.edu.tr

a orcid.org/0000-0003-3473-9869; b orcid.org/0000-0001-5324-8892

DOI: http://dx.doi.org/10.17515/resm2020.241en1217

Res. Eng. Struct. Mat. Vol. 7 Iss. 4 (2021) 539-550
} 
ARC on short circuit current (Jsc), open circuit voltage ( $V_{\text {oc }}$ ), fill factor (FF) and efficiency ( $\eta$ ) of silicon solar cell using Silvaco software [9]. Islam et. al used Sentaurus TCAD in simulation of ITO/ $\mathrm{Si}_{3} \mathrm{~N}_{4} / \mathrm{ZnO}: \mathrm{Al}$ as antireflection coating and studied the effect of ARC in $\mathrm{J}_{\mathrm{sc}}, \mathrm{V}_{\mathrm{OC}}$ and efficiency of silicon solar cells [8]. These studies of antireflection coatings using simulation softwares have shown a significant increase in $\mathrm{J}_{\mathrm{sc}}$, and $\eta$ of antireflection coated silicon solar cell when compared to an uncoated solar cell. Due to the vast amount of research data that are compiled in order to make these softwares, they can predict and give accurate output on up to sub-90nm semiconductor manufacturing processes and provide atomic-level accuracy [15].

Various mathematical equations are available for solving the reflectance spectra of solar cells with ARC. The 'transfer matrix method' is the most commonly used equation for solving reflectance spectra of multi-layer thin film stacks due to abundance of available sources [16-18]. For 'N number' layers of thin films deposited on a substrate, multiple reflected and transmitted light are accounted and calculated using a transfer matrix form of each layer. Another way of calculating the reflectance spectra of ARC is through the use of 'Fresnel's equations' using Rouard's Method $[19,20]$. In this method, the reflectance and transmittance coefficients are calculated using Fresnel's equations which are simplified by Rouard's method. The total reflectance can be calculated by adding all the interacting light waves at the top surface of the ARC. Application of single layer antireflection coating (SLARC) equations using O.S. Heaven's equations, transfer matrix method, and Fresnel equations are available in literature. Besides that, explanations of Fresnel equations for multilayer combinations along with application in solar cells is crucial for simulating its effects for future design of solar cells.

In this work, basic structures and working principles behind double and multi-layer antireflection coatings were presented. Fresnel's equation with the use of Rouard's method were studied and compared with commonly used transfer matrix method in order to solve the reflectance spectra of double and multi-layer ARC. Introduced solutions are valid not only for silicon substrate but also for any type of substrate. Equations regarding the reflectivity of different polarities of light with respect to the incidence angle of the light source were also shown with detailed calculations. Additionally, PC1D simulation software was used to obtain various characteristics and behaviors of a silicon solar cell with up to three layers of antireflection coating which was also used for comparison purposes.

\section{Simulation Model and Fresnel's Equations}

A conventional p-type silicon solar cell consists of $<$ front metallic contacts/antireflection coating/n-type emitter/p-type silicon substrate/p-type back surface field/back contact>. An effective ARC structure has an important role for maximum absorption and minimum reflection of the incoming light. Light is an electromagnetic wave which have both electric and magnetic fields propagating perpendicularly with each other. The light emitted by the sun incident to the Earth's surface is a non-polarized light [21]. The direction of the oscillation of the electric field in an electromagnetic wave determines the polarization direction. S-polarization or sometimes known as 'perpendicular polarization' occurs when the direction of propagation of electric field is perpendicular to the incident surface while P-polarization or 'parallel polarization' occurs when the electric field is parallel to the incident surface [18]. The light emitted by the sun is a combination of different wavelengths and polarization combined with each other which results in a white light that can be seen by the naked eye. When sunlight hits an interface, i.e. silicon, the intensity of reflection will vary depending on the polarization and angle of incidence. Those incoming waves resulting in total wave either by constructively or destructively interfering with each other. Fig. $1 \mathrm{a}$ and $1 \mathrm{~b}$ illustrates the various interacting waves between the substrate and the incident medium for double layer antireflection coating (DLARC) and multi-layer 
antireflection coating (MLARC) composed of three layers on silicon substrate. The variable $\mathrm{n} 0$ stands for the refractive index of air while ns stands for refractive index of the silicon substrate. The refractive index of antireflection coating in between air and silicon are denoted with subsequent numbers from top to bottom layer.

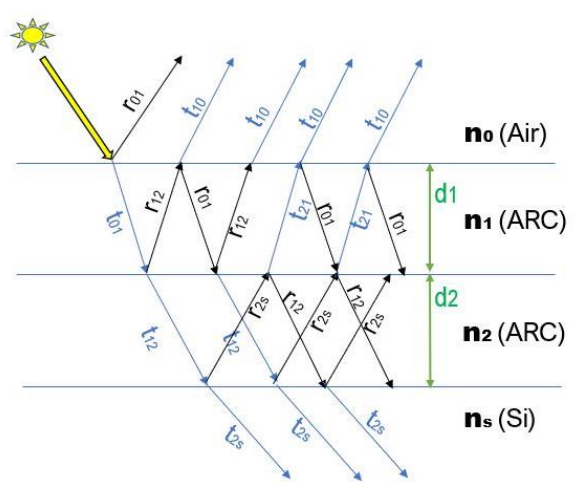

(a)

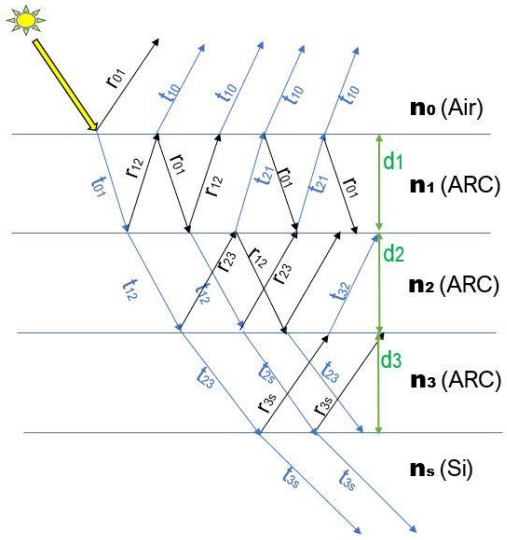

(b)

Fig. 1 (a) Interaction of light waves in a silicon, (b) Interaction of light waves in a silicon solar cell with DLARC solar cell with MLARC

When incoming light hits an interface and propagates from one medium to another medium with different refractive index, while a part of the light is transmitted or absorbed into the latter medium, some portion of the light is reflected back, as explained in literature [8,22-24]. During this transaction, the diffraction of transmitted light bends in an angle and changes the angle of propagation. At the end, the sum of all the interacting waves at the top surface figures the total intensity of the reflected light in the solar cell. Therefore, double, and multi-layer ARC can reduce the reflection more effectively than that of the single layer ARC by utilizing destructive interference of waves in multiple interfaces.

\section{Double and Multi-Layer Anti Reflection Coating (DLARC and MLARC)}

A highly efficient solar cell must have very low reflectance in wide range of wavelengths, so it can utilize as much the energy from the sun. SLARC can only achieve near-zero reflection at a specific wavelength. In order to further reduce the reflections in wider range of wavelengths with DLARC and MLARC, a combination of lower refractive index material as the outer layer and higher refractive index at the bottom layer can be stacked to lower average reflectance in wider range of wavelengths compared to SLARC. DLARC and MLARC have more complex reflections which can interfere with other reflected and transmitted waves that results in a lower total reflectance [21]. As a result, detailed calculations are needed to solve the total reflection at the surface of the solar cell due to the multiple interacting waves in a silicon solar cell with DLARC and MLARC (Fig. 1a and 1b).

\subsection{DLARC Equations Using Fresnel's Equation and Rouard's Method}

Rouard's method simplifies the calculation of the reflectance spectra of any ' $N$ ' number of dielectric stacks deposited on a substrate. Reflectance spectra of the solar cell with DLARC can be solved by following equations $[8,19,24]$ : 


$$
\begin{gathered}
\delta_{1}=\frac{2 \pi n_{1} d_{1} \cos \theta_{1}}{\lambda_{o}} \\
\delta_{2}=\frac{2 \pi \mathrm{n}_{2} \mathrm{~d}_{2} \cos \theta_{2}}{\lambda_{\mathrm{o}}} \\
\mathrm{r}_{1}=\mathrm{r}_{0,1}+\left[\left(\mathrm{t}_{0,1} \mathrm{e}^{-\mathrm{i} \delta_{1}}\right)\left(\mathrm{r}_{1,2} \mathrm{e}^{-\mathrm{i} \delta_{1}}\right)\left(\mathrm{t}_{1,0}\right)\right] \\
+\left[\left(\mathrm{t}_{0,1} \mathrm{e}^{-\mathrm{i} \delta_{1}}\right)\left(\mathrm{t}_{1,2} \mathrm{e}^{-\mathrm{i} \delta_{2}}\right)\left(\mathrm{r}_{2, \mathrm{~s}} \mathrm{e}^{-\mathrm{i} \delta_{2}}\right)\left(\mathrm{t}_{2,1} \mathrm{e}^{-\mathrm{i} \delta_{1}}\right)\left(\mathrm{t}_{1,0}\right)\right] \\
+\left[\left(\mathrm{t}_{0,1} \mathrm{e}^{-\mathrm{i} \delta_{1}}\right)\left(\mathrm{r}_{1,2} \mathrm{e}^{-\mathrm{i} \delta_{1}}\right)\left(\mathrm{r}_{1,0} \mathrm{e}^{-\mathrm{i} \delta_{1}}\right)\left(\mathrm{r}_{1,2} \mathrm{e}^{-\mathrm{i} \delta_{1}}\right)\left(\mathrm{t}_{1,0}\right)\right] \\
+\cdots
\end{gathered}
$$

Simplifying by using Rouard's method

$$
\begin{aligned}
& \mathrm{r}_{2}=\frac{\mathrm{r}_{1,2}+\mathrm{r}_{2, \mathrm{~s}} \mathrm{e}^{-2 \mathrm{i} \delta_{2}}}{1+\mathrm{r}_{1,2} \mathrm{r}_{2, \mathrm{~s}} \mathrm{e}^{-2 \mathrm{i} \delta_{2}}} \\
& \mathrm{r}_{1}=\frac{\mathrm{r}_{0,1}+\mathrm{r}_{2} \mathrm{e}^{-2 \mathrm{i} \delta_{1}}}{1+\mathrm{r}_{0,1} \mathrm{r}_{2} \mathrm{e}^{-2 \mathrm{i} \delta_{1}}} \\
& R=\left|\frac{r_{1(s)}^{2}+r_{1(p)}^{2}}{2}\right|+\cdots
\end{aligned}
$$

\subsection{DLARC Equations Using Transfer Matrix Method}

The transfer matrix method alternative for double layer ARC can also be calculated by using the following equation:

$$
\begin{gathered}
n_{0}^{2}\left[\cos \delta_{1} \cos \delta_{2}-\frac{n_{2}}{n_{1}} \sin \delta_{1} \sin \delta_{2}\right]^{2}+\left(n_{0} n_{3}\right)^{2}\left[\frac{\cos \delta_{1} \sin \delta_{2}}{n_{2}}+\frac{\cos \delta_{2} \sin \delta_{1}}{n_{1}}\right]^{2}+ \\
R=\frac{\left[n_{1} \sin \delta_{1} \cos \delta_{2+} n_{2} \sin \delta_{2} \cos \delta_{1}\right]^{2}+n_{3}^{2}\left[\cos \delta_{1} \cos \delta_{2}-\frac{n_{1}}{n_{2}} \sin \delta_{1} \sin \delta_{2}\right]^{2}-2 n_{0} n_{s}}{n_{0}^{2}\left[\cos \delta_{1} \cos \delta_{2}-\frac{n_{2}}{n_{1}} \sin \delta_{1} \sin \delta_{2}\right]^{2}+\left(n_{0} n_{3}\right)^{2}\left[\frac{\cos \delta_{1} \sin \delta_{2}}{n_{2}}+\frac{\cos \delta_{2} \sin \delta_{1}}{n_{1}}\right]^{2}+} \\
{\left[n_{1} \sin \delta_{1} \cos \delta_{2+} n_{2} \sin \delta_{2} \cos \delta_{1}\right]^{2}+n_{3}^{2}\left[\cos \delta_{1} \cos \delta_{2}-\frac{n_{1}}{n_{2}} \sin \delta_{1} \sin \delta_{2}\right]^{2}+2 n_{0} n_{s}}
\end{gathered}
$$

\subsection{MLARC Equations Using Fresnel's Equation and Rouard's Method}

In order to further reduce the reflectance in a broad spectrum, multi-layer combination of different dielectric materials can be stacked on top of each other. The equation used for solving the total reflectance of MLARC can be calculated using Rouard's method by:

For k number of layers:

$$
\delta_{\mathrm{k}}=\frac{2 \pi \mathrm{n}_{\mathrm{k}} \mathrm{d}_{\mathrm{k}} \cos \theta_{\mathrm{k}}}{\lambda_{0}}
$$

For the $\mathrm{k}^{\text {th }}$ layer:

$$
r_{k}=\frac{\left(r_{k-1, k}\right)+\left(r_{k, k+1}\right) e^{-2 i \delta_{k}}}{1+\left(r_{k-1, k}\right)\left(r_{k, k+1}\right) e^{-2 i \delta_{k}}}
$$


For $k$-1 layer until $k=2$ :

$$
\begin{aligned}
& r_{k}=\frac{\left(r_{k-1, k}\right)+\left(r_{k}\right) e^{-2 i \delta_{k}}}{1+\left(r_{k-1, k}\right)\left(r_{k}\right) e^{-2 i \delta_{k}}} \\
& r_{1}=\frac{r_{0,1}+r_{2} e^{-2 i \delta_{1}}}{1+r_{0,1} r_{2} e^{-2 i \delta_{1}}}
\end{aligned}
$$

Then the total reflectance at the surface of ARC can be calculated by Eq. (6). $n_{1}$ and $n_{2}$ are the refractive indexes of the $1^{\text {st }}$ and $2^{\text {nd }}$ medium, respectively. $\theta_{1}$ is the angle of incidence from the source to medium $1, \theta_{2}$ is the angle of light entering from medium 1 to $2, r_{s, p}$ is the coefficient of reflection for $\mathrm{s}$ and $\mathrm{p}$ polarizations, $t_{s, p}$ is the coefficient of transmission for $s$ and p polarizations. $d_{1}$ and $d_{2}$ are the thicknesses of the medium 1 and 2, respectively in $n m$. $\delta_{1}$ is the phase change of the wave, $\delta_{2}$ is the phase change at the $2^{\text {nd }}$ layer, $r_{1}$ is the total reflection coefficient, $r_{2}$ is the total reflectance coefficient at the $2^{\text {nd }}$ layer, $\lambda_{0}$ is the wavelength at free space in $n m, r_{a, b}$ is the coefficients of reflection from medium a to $\mathrm{b}, t_{a, b}$ is the coefficients of transmission from medium a to $b, R$ is the total reflection at the surface of ARC.

\section{DLARC and MLARC Simulation Results}

Fig. 2 shows the reflectance spectra of silicon surface with DLARC comparing to the SLARC and bare silicon surface calculated by Fresnel equations. The values of refractive index ' $n$ ' and extinction coefficient ' $k$ ' of Silicon [25], $\mathrm{TiO}_{2}$ [26], $\mathrm{MgF}_{2}$ [27], $\mathrm{ZnS}$ [28] and $\mathrm{SiN}_{\mathrm{x}}$ [29] were also obtained from [30,31]. $\mathrm{SiN}_{\mathrm{x}}$ and $\mathrm{ZnS}$ SLARC with various thicknesses were given in Fig. $2 \mathrm{a}$ and $2 \mathrm{~b}$ where a significant decrease of the reflectance is clear comparing to the bare flat silicon surface. Minimum of spectra shifts to the higher wavelengths as the thickness of SLARC increases. Experimental measurement of $\mathrm{TiO}_{2} / \mathrm{SiN}_{\mathrm{x}}$ DLARC was performed in a polished p-type FZ Silicon wafer and deposited using PECVD at a substrate temperature of $200^{\circ} \mathrm{C}$ [32]. $\mathrm{MgF}_{2} / \mathrm{ZnS}$ DLARC was deposited using electron beam with a substrate temperature of $125^{\circ} \mathrm{C}$ for $\mathrm{ZnS}$ and $200^{\circ} \mathrm{C}$ for $\mathrm{MgF}_{2}$ [33]. These experimental data were used to assess the accuracy of the calculations under consent of related reference. Comparisons found to be relatively in agreement with simulated data in current work. Table 1 shows the average reflectance of each device using various methodologies. Simulated data were in good agreement with the experimental data especially in visible spectrum between $400 \mathrm{~nm}$ to $700 \mathrm{~nm}$ where the solar intensity is in its maximum. Additionally, spectra of the $\mathrm{TiO}_{2} / \mathrm{SiN}_{\mathrm{x}}$ and $\mathrm{MgF}_{2} / \mathrm{ZnS}$ DLARC with different thicknesses in stacks were given in Fig. 2e and 2f, respectively. Minimum of the $\mathrm{TiO}_{2} / \mathrm{SiN}_{\mathrm{x}}$ spectra shifts through the higher wavelengths as the thickness of the stack increases. Reflectance of $\mathrm{MgF}_{2} / \mathrm{ZnS}$ DLARC coated surface in the range of 400-800 $\mathrm{nm}$ increases significantly when the thickness of $\mathrm{MgF}_{2}$ is less than $100 \mathrm{~nm}$ in the stack. The one minimum characteristic of $\mathrm{TiO}_{2} / \mathrm{SiN}_{\mathrm{x}}$ DLAR coated wafers with high average reflectance than that of the wafers coated with $\mathrm{MgF}_{2} / \mathrm{ZnS}$ is due to the high/low 'n' order of the stack where $\mathrm{MgF}_{2} / \mathrm{ZnS}$ has a gradually increasing order of ' $n$ ' with optimum values from surface to bulk. 


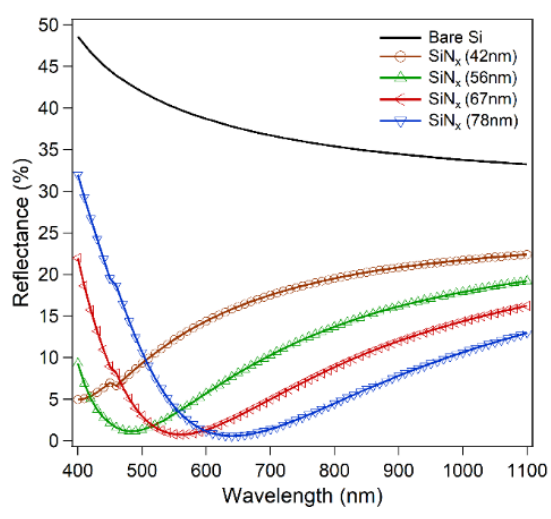

(a)

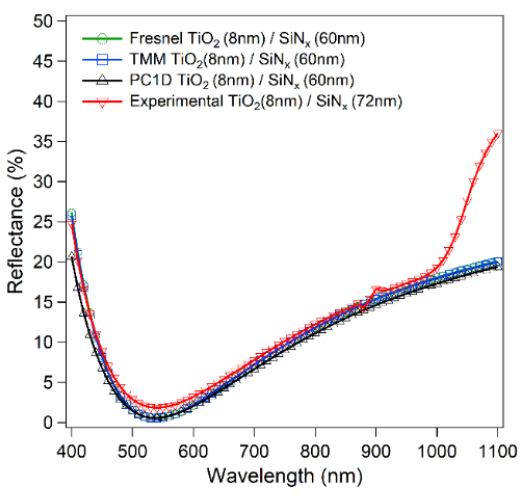

(c)

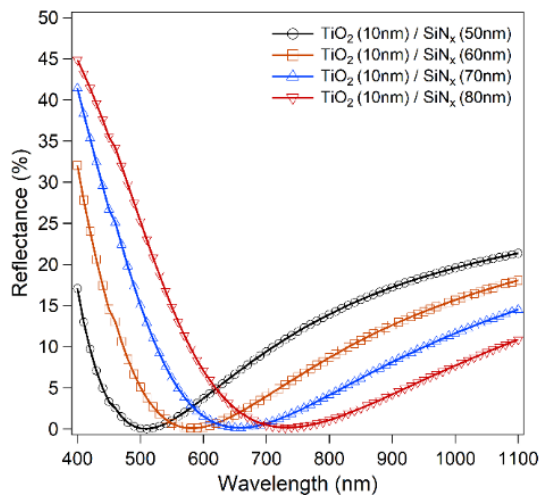

(e)

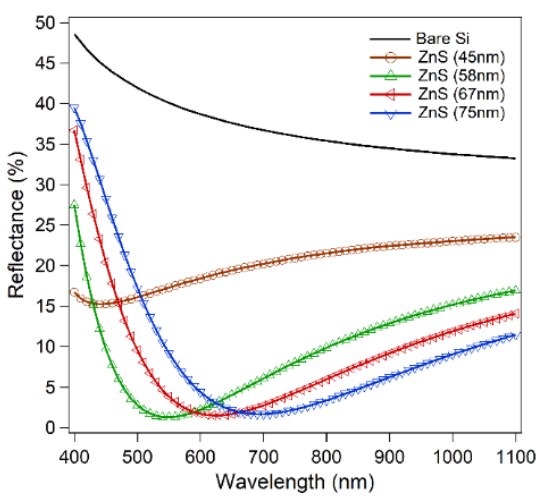

(b)

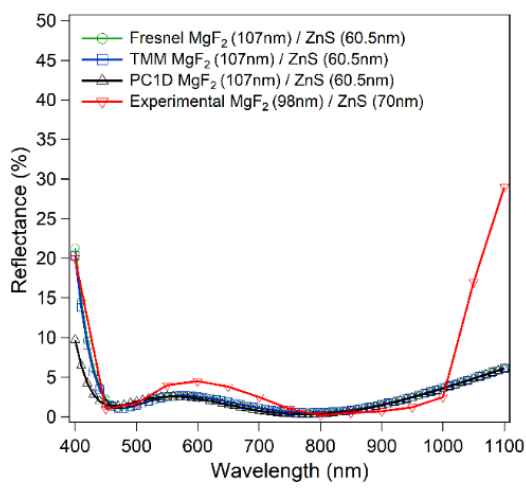

(d)

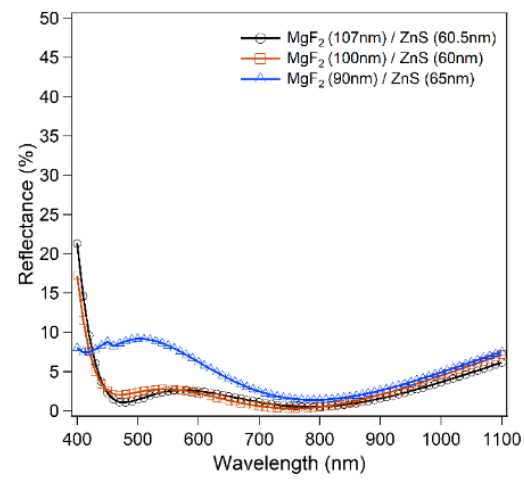

(f)

Fig. 2 Reflectance spectra of silicon substrate with (a) SiN $\mathrm{N}_{\mathrm{x}}$ SLARC, (b) ZnS SLARC, (c)

$\mathrm{TiO}_{2} / \mathrm{SiN}_{\mathrm{x}}$ DLARC, (d) $\mathrm{MgF}_{2} / \mathrm{ZnS}$ DLARC, (e) $\mathrm{TiO}_{2} / \mathrm{SiN}_{\mathrm{x}}$ DLARC with various thicknesses, (f) $\mathrm{MgF}_{2} / \mathrm{ZnS}$ DLARC with various thicknesses 
Table 1. Average reflectance (400-1100 $\mathrm{nm}$ ) of silicon substrate with DLARC achieved by using different methods

\begin{tabular}{ccccc}
\hline & Fresnel's Eq. & TMM & PC1D & Experimental \\
\hline $\mathrm{TiO}_{2} / \mathrm{SiN}_{\mathrm{x}}$ & 10.899 & 10.848 & 10.107 & 12.729 \\
$\mathrm{MgF}_{2} / \mathrm{ZnS}$ & 2.802 & 2.755 & 2.266 & 5.973 \\
\hline
\end{tabular}

$\mathrm{MgF}_{2} / \mathrm{ZnS}$ combination provided a $2.2 \%$ average reflectance based on simulation with PC1D. Average reflection of $\mathrm{MgF}_{2} / \mathrm{ZnS}$ DLARC was estimated by Fresnel Equations as $2.8 \%$ which is slightly closer estimation than that of the TMM method.

Alternative MLARC simulations using combination of three layers of ARC on silicon substrate were shown in Fig. 3a and 3b. Table 2 summarizes the average reflectance of each device using different methodologies.

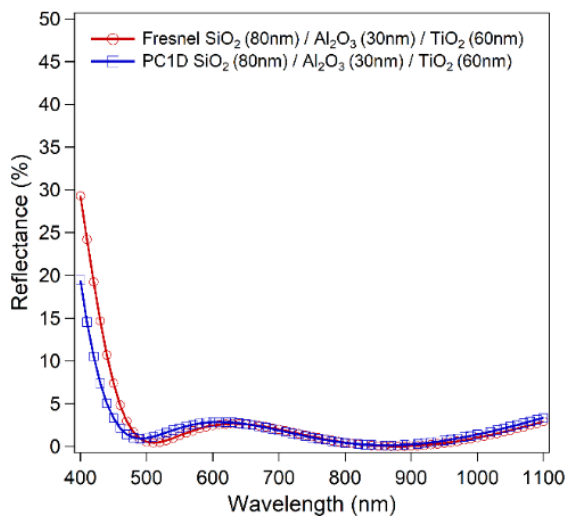

(a)

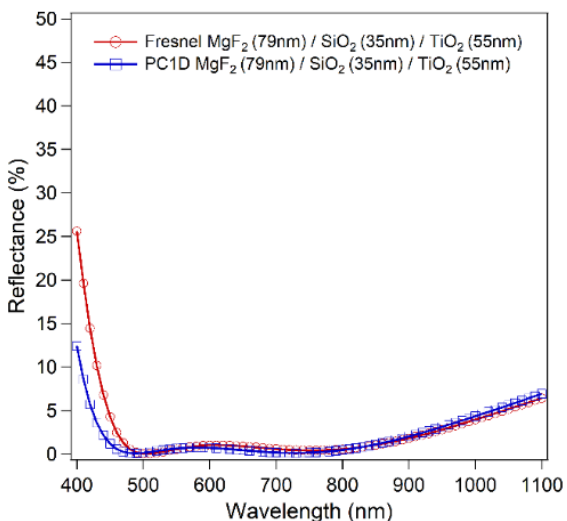

(b)

Fig. 3 Reflectance spectra of silicon substrate with (a) $\mathrm{SiO}_{2} / \mathrm{Al}_{2} \mathrm{O}_{3} / \mathrm{TiO}_{2} \mathrm{MLARC}$ and (b) $\mathrm{MgF}_{2} / \mathrm{SiO}_{2} / \mathrm{TiO}_{2} \mathrm{MLARC}$

Table 2. Average reflectance (400-1100 nm) of of silicon substrate with MLARC achieved by different methods

\begin{tabular}{lcl}
\hline & Fresnel's Eq. & PC1D \\
\cline { 2 - 3 } $\mathrm{SiO}_{2} / \mathrm{Al}_{2} \mathrm{O}_{3} / \mathrm{TiO}_{2}$ & 2.799 & 2.111 \\
$\mathrm{MgF}_{2} / \mathrm{SiO}_{2} / \mathrm{TiO}_{2}$ & 2.720 & 2.228 \\
\hline
\end{tabular}

$\mathrm{TiO}_{2}$ with high ' $\mathrm{n}$ ' of 2.59 (at $550 \mathrm{~nm}$ ) was used as the bottom layer of the ARC for MLARC where $\mathrm{TiO}_{2}$ with lower ' $\mathrm{n}$ ' of 2.11 (at $550 \mathrm{~nm}$ ) were used for DLARC which can be achieved by different processing conditions [23]. Although MLARC layers provides similar reflection values, $\mathrm{MgF}_{2} / \mathrm{SiO}_{2} / \mathrm{TiO}_{2}$ combination achieved the best results in device performance due to very low reflectance at the peak of solar spectrum with high spectral irradiance. Estimated average reflectance of the silicon surface with $\mathrm{SiO}_{2} / \mathrm{Al}_{2} \mathrm{O}_{3} / \mathrm{TiO}_{2}$ and $\mathrm{MgF}_{2} / \mathrm{SiO}_{2} / \mathrm{TiO}_{2}$ MLARC were $2.8 \%$ and $2.72 \%$, respectively. Reflectance of $\mathrm{SiO}_{2} / \mathrm{Al}_{2} \mathrm{O}_{3} / \mathrm{TiO}_{2}$ coated wafers provides less reflectivity especially in the range of 800 $1100 \mathrm{~nm}$ than that of the wafers coated with $\mathrm{MgF}_{2} / \mathrm{SiO}_{2} / \mathrm{TiO}_{2}$. On the other hand, $\mathrm{MgF}_{2} / \mathrm{SiO}_{2} / \mathrm{TiO}_{2}$ coated wafers have lower reflectivity in the range of 500-800 nm which covers the peak region of solar spectrum. 
For the analysis of DLARC and MLARC, both TMM and Fresnel calculations can predict the behavior of reflectance spectra of antireflection coatings with different combinations of dielectric materials. Although, results by Fresnel equations were slightly closer to the experimental values than that of the values achieved by TMM, both techniques were in a good agreement with the experimental measurements. In general, a combination of a lower refractive index materials such as $\mathrm{MgF}_{2}$ or $\mathrm{SiO}_{2}$ with refractive index of less than 1.5 can be appropriate for the first layer while higher refractive index materials such as $\mathrm{TiO}_{2}$ and $\mathrm{ZnS}$ are suitable materials at the bottom layer.

In case of double or multi-layer stackings, combination of materials with lower refractive index to higher refractive index in ascending order can have achieve a lower reflectance spectrum on wide range of wavelengths. Various data show the difference in the values of $n$ and $k$ of the same material due to different deposition techniques and parameters used such as annealing temperature $[27,28]$. The output spectra of the simulation would vary depending on different values of refractive index and extinction coefficients of materials that are used. Due to the gradual refractive indexes and thicknesses of materials in $\mathrm{MgF}_{2} / \mathrm{ZnS}$ structure a reduced overall reflectivity could be achieved in DLARC. Spectra was achieved in $\mathrm{W}$ shape which means reflectivity reaches minimum corresponding to two wavelengths and contribute to reduce reflectivity over a broad range of spectrum [34]. MLARC provides further reduced reflectance especially in visible range and in overall spectrum. It is worth to bear in mind that the properties of the materials other than ARC effect plays an important role on silicon solar cell performances as well, such as passivation of defects etc. Therefore, all materials with good ARC may not lead high efficiencies as expected in real devices.

\section{Silicon Solar Cell Simulations by PC1D}

PC1D version 5.9 is a semiconductor modeling software made by UNSW Australia which is widely used in solar cell research [14]. High efficiency silicon solar cell with DLARC and MLARC were simulated with PC1D. Simulations were carried out by fixing the solar cell parameters except of the ARC films. The same ARC films were applied with the same thicknesses as in Figs. 2-3 to investigate the impact of each ARC film on the performance of a silicon based solar cell. Table 3 shows the parameters of the solar cell that were used in the simulation.

Table 3. Solar cell device parameters using PC1D

\begin{tabular}{cc}
\hline Front surface texture depth & $3 \mu \mathrm{m}$ \\
Internal optical reflectance & Enabled \\
Series Resistance & $0.8 \Omega$ \\
Shunt Resistance & $50000 \Omega$ \\
Emitter Sheet Resistance & $60 \Omega / \mathrm{square}$ \\
Thickness & $180 \mu \mathrm{m}$ \\
Front diffusion (N-type) & $2 \times 10^{20} \mathrm{~cm}^{-3}$ peak \\
Rear diffusion (P-type) & $3 \times 10^{18} \mathrm{~cm}^{-3}$ peak \\
Front SRV & $1 \times 10^{2} \mathrm{~cm}_{/}$ \\
Rear SRV & $1 \times 10^{6} \mathrm{~cm} / \mathrm{s}$ \\
Bulk recombination & $\tau_{\mathrm{n}}=\tau_{\mathrm{p}}=30 \mu \mathrm{s}$ \\
Temperature & $25^{\circ} \mathrm{C}$ \\
\hline
\end{tabular}


Table 4 presents the electrical performance of each solar cell with and without ARC where relationship of the electrical parameters can be given as $\eta=\left(V_{M P} \times J_{M P}\right) / P_{I N}=$ $\left(V_{O C} \times J_{S C} \times F F\right) / P_{I N} . \eta$ is the conversion efficiency, $V_{M P}$ and $J_{M P}$ are the voltage and current at the maximum power point, respectively. $P_{I N}$ is the standard 1 sun input power for measurements $\left(100 \mathrm{~mW} / \mathrm{cm}^{2}\right)$. The values of refractive index used in the simulation were obtained $[27,28] . I-V$ curves of the best solar cells with ARC compared with the simulated solar cell without ARC is shown in Fig. 4. The antireflection effect of DLARC and MLARC layers on the short circuit current density can be clearly confirmed.

Table 4. Performance of solar cells with various layers of ARC

\begin{tabular}{|c|c|c|c|c|c|c|c|}
\hline & $\begin{array}{c}\text { ARC film } \\
\text { (thickness in } \mathrm{nm} \text { ) }\end{array}$ & $\begin{array}{c}\text { Jsc } \\
(\mathrm{mA} / \\
\left.\mathrm{cm}^{2}\right)\end{array}$ & $\begin{array}{l}\text { Voc } \\
(\mathrm{mV})\end{array}$ & $\begin{array}{c}\text { JMP } \\
(\mathrm{mA} / \\
\left.\mathrm{cm}^{2}\right)\end{array}$ & $\begin{array}{l}\mathrm{V}_{\mathrm{MP}} \\
(\mathrm{mV})\end{array}$ & $\begin{array}{l}\text { FF } \\
(\%)\end{array}$ & $\begin{array}{c}\eta \\
(\%)\end{array}$ \\
\hline No ARC & No ARC & 26.28 & 609.7 & 24.25 & 517 & 78.25 & 12.54 \\
\hline \multirow{2}{*}{ SLARC } & $\operatorname{SiN}_{x}(67)$ & 37.03 & 618.7 & 35.00 & 508.1 & 77.62 & 17.79 \\
\hline & $\operatorname{ZnS}(67)$ & 36.18 & 618.1 & 33.76 & 515.2 & 77.78 & 17.39 \\
\hline \multirow[b]{2}{*}{ DLARC } & $\mathrm{TiO}_{2}(8) / \mathrm{SiN}_{\mathrm{x}}(60)$ & 37.08 & 618.7 & 35.03 & 508.6 & 77.66 & 17.82 \\
\hline & $\begin{array}{c}\mathrm{MgF}_{2}(107) / \mathrm{ZnS} \\
(60.5)\end{array}$ & 39.58 & 620.4 & 36.96 & 515.2 & 77.55 & 19.04 \\
\hline \multirow{2}{*}{ MLARC } & $\begin{array}{c}\mathrm{SiO}_{2}(80) / \mathrm{Al}_{2} \mathrm{O}_{3}(30) / \mathrm{Ti} \\
\mathrm{O}_{2}(60)\end{array}$ & 39.45 & 620.4 & 36.91 & 514.3 & 77.56 & 18.98 \\
\hline & $\begin{array}{c}\mathrm{MgF}_{2}(79) / \mathrm{SiO}_{2}(35) / \mathrm{Ti} \\
\mathrm{O}_{2}(55)\end{array}$ & 39.71 & 620.5 & 37.01 & 516.2 & 77.53 & 19.10 \\
\hline
\end{tabular}

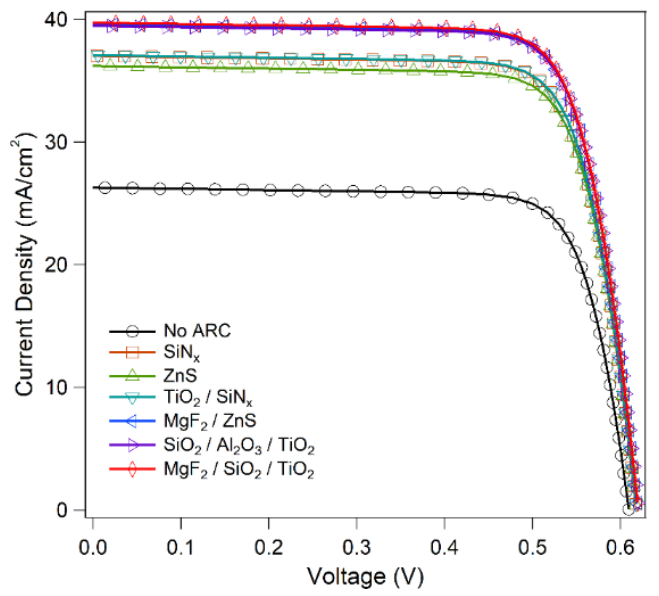

Fig. $4 I$ - $V$ curve of best solar cells with SLARC, DLARC and MLARC compared with the solar cell without ARC

An uncoated solar cell reflects more than $35 \%$ or one third portion of incoming light due to inherent reflective properties of silicon. Increase in conversion efficiency can be confirmed by DLAR and MLAR coated solar cells due to the significant decrease in reflectance. Improvement in solar cell performances were achieved by using $\mathrm{MgF}_{2} / \mathrm{ZnS}$ as DLARC and $\mathrm{MgF}_{2} / \mathrm{SiO}_{2} / \mathrm{TiO}_{2}$ as MLARC. The best $J_{S C}$ values of the solar cells with MLARC is $39.71 \mathrm{~mA} / \mathrm{cm}^{2}$ which is significantly higher than the $J s c$ of uncoated cell $\left(26.28 \mathrm{~mA} / \mathrm{cm}^{2}\right)$ due to the impact of ARC coatings on trapping the incoming light. As a result of using ARCs, 
the best simulated efficiencies for corresponding cells with SLARC was $17.79 \%$ with $\operatorname{SiN}_{\mathrm{x}}$ which was improved up to $19.1 \%$ with $\mathrm{MgF}_{2} / \mathrm{SiO}_{2} / \mathrm{TiO}_{2}$ MLARC. DLARC provided a $J_{S C}$ of $39.58 \mathrm{~mA} / \mathrm{cm}^{2}$ leading an efficiency of $19 \%$ owing to the reduced reflection in a broad range of spectrum. It is worth to mention that considering the properties of materials and interfaces in the device depend on the source of the materials and the deposition/processing techniques, it is challenging to compare simulation results with real devices based on the antireflection-only effect with exact set of device parameters. However, simulations and experimental results can be compared by the total increment in the conversion efficiency for an estimation. For instance, an increase on efficiency of $6.1 \%$ with $\mathrm{MgF}_{2} / \mathrm{ZnS}$ DLARC was reported comparing to the solar cells without an ARC [34] which is similar to the results in current work providing the possible increase of $6.32 \%$ on efficiency with $\mathrm{MgF}_{2} / \mathrm{ZnS}$ DLARC. One of the conclusions can be that a significant reduction of surface reflectance achieved by an optimized DLARC for silicon solar cells would be sufficient for high efficiencies. However, alternative ARC structures can be developed by utilizing Fresnel equations for more complex solar cells such as multijunction, perovskite or other emerging solar cells.

\section{Conclusion}

The reflectance spectra of double and multi-layer antireflection coatings based on Fresnel equations were studied in this work. Various experimental measurements were used to validate the accuracy of the equations besides the comparison of results with transfer matrix method. PC1D simulation results were also added to further validate and measure the overall performance of each combination of ARC. The average reflection of the solar cell without any antireflection coating from 400 to $1100 \mathrm{~nm}$ around $37 \%$ which results to a huge loss in the overall efficiency of the solar cell due to the reflection of more than $1 / 3$ of incoming light. It was shown that a proper selection of antireflection coating material with optimum thickness can result to such huge decrease of reflectance from the surface and increase in the overall performance of solar cells. And the Fresnel equations can be supportive for estimating the reflectance behavior of coated surfaces. For the $\mathrm{MgF}_{2} / \mathrm{ZnS}$ DLARC stack, it was concluded that the thickness of $\mathrm{MgF}_{2}$ less than $100 \mathrm{~nm}$ is not favorable due to the significant increase of the reflectance of $\mathrm{MgF}_{2} / \mathrm{ZnS}$ DLARC coated surface in the range of $400-800 \mathrm{~nm}$, from $2 \%$ to up to peak of $10 \%$. Estimated average reflectance of the silicon surface when with $\mathrm{SiO}_{2} / \mathrm{Al}_{2} \mathrm{O}_{3} / \mathrm{TiO}_{2}$ and $\mathrm{MgF}_{2} / \mathrm{SiO}_{2} / \mathrm{TiO}_{2}$ MLARC were $2.8 \%$ and $2.72 \%$, respectively. $\mathrm{SiO}_{2} / \mathrm{Al}_{2} \mathrm{O}_{3} / \mathrm{TiO}_{2}$ coating wafers provides less reflectivity than that of the wafers coated with $\mathrm{MgF}_{2} / \mathrm{SiO}_{2} / \mathrm{TiO}_{2}$ especially in the range of $800-1100 \mathrm{~nm}$. On the other hand, $\mathrm{MgF}_{2} / \mathrm{SiO}_{2} / \mathrm{TiO}_{2}$ coated wafers have lower reflectivity in the range of $500-800$ $\mathrm{nm}$ which is valuable as it covers the peak region of solar spectrum. $\mathrm{MgF}_{2} / \mathrm{SiO}_{2} / \mathrm{TiO}_{2}$ MLARC achieved the overall best result with simulated efficiency of $19.1 \%$. Selection and combination of materials are crucial in achieving the reduced reflectance which results to a more efficient device. Therefore, an accurate simulation can be rewarding for researchers and manufacturers in selecting the best combination of materials to optimize their devices.

\section{References}

[1] Yoshikawa K, Kawasaki H, Yoshida W, Irie T, Konishi K, Nakano K, et al. Silicon heterojunction solar cell with interdigitated back contacts for a photoconversion efficiency over 26\%. Nat Energy. 2017;2(5). https://doi.org/10.1038/nenergy.2017.32

[2] Benick J, Richter A, Müller R, Hauser H, Feldmann F, Krenckel P, et al. High-Efficiency nType HP mc Silicon Solar Cells. IEEE J Photovoltaics. 2017;7(5):1171-5. https://doi.org/10.1109/JPHOTOV.2017.2714139

[3] Uzum A, Kuriyama M, Kanda H, Kimura Y, Tanimoto K, Fukui H, et al. Sprayed and SpinCoated Multilayer Antireflection Coating Films for Nonvacuum Processed Crystalline 
Silicon Solar Cells. Int J Photoenergy. 2017;2017. https://doi.org/10.1155/2017/3436271

[4] El amrani A, Menous I, Mahiou L, Tadjine R, Touati A, Lefgoum A. Silicon nitride film for solar cells. Renew 2008;33(10):2289-93. https://doi.org/10.1016/j.renene.2007.12.015

[5] Liu B, Zhong S, Liu J, Xia Y, Li C. Silicon nitride film by inline PECVD for black silicon solar cells. Int J Photoenergy. 2012;2012:2-7. https://doi.org/10.1155/2012/971093

[6] Hofstetter J, Cafiizo C, Luque A. Optimisation of SiNx:H anti-reflection coatings for silicon solar cells. 2007;00(c):131-4. https://doi.org/10.1109/SCED.2007.383961

[7] Kanda H, Uzum A, Harano N, Yoshinaga S, Ishikawa Y, Uraoka Y, et al. Al203/TiO2 double layer anti-reflection coating film for crystalline silicon solar cells formed by spray pyrolysis. Energy Sci Eng. 2016;4(4):269-76. https://doi.org/10.1002/ese3.123

[8] Kanmaz I, Mandong AM, Uzum A. Solution-based hafnium oxide thin films as potential antireflection coating for silicon solar cells. J Mater Sci Mater Electron [Internet]. 2020;31(23):21279-87. https://doi.org/10.1007/s10854-020-04640-9

[9] Uzum A, Kuriyama M, Kanda H, Kimura Y, Tanimoto K, Ito S. Non-vacuum processed polymer composite antireflection coating films for silicon solar cells. Energies. 2016;9(8). https://doi.org/10.3390/en9080633

[10] Abu-Shamleh A, Alzubi H, Alajlouni A. Optimization of antireflective coatings with nanostructured TiO2 for GaAs solar cells. Photonics Nanostructures - Fundam Appl [Internet]. 2021;43(April 2020):100862. https://doi.org/10.1016/i.photonics.2020.100862

[11] Khan SB, Zhang Z, Lee SL. Single component: Bilayer TiO2 as a durable antireflective coating. J Alloys Compd. 2020;834. https://doi.org/10.1016/i.jallcom.2020.155137

[12] Islam K, Alnuaimi A, Ally H, Nayfeh A. ITO, Si3N4 and ZnO:Al - Simulation of different anti-reflection coatings (ARC) for thin film a-Si:H solar cells. Proc - UKSim-AMSS 7th Eur Model Symp Comput Model Simulation, EMS 2013. 2013;673-6. https://doi.org/10.1109/EMS.2013.112

[13] Abdullah H, Lennie A, Ahmad I. Modelling and simulation single layer Anti-Reflective Coating of $\mathrm{ZnO}$ and $\mathrm{ZnS}$ for silicon solar cells using silvaco software. Vol. 9, Journal of Applied Sciences. 2009. p. 1180-4. https://doi.org/10.3923/jas.2009.1180.1184

[14] Clugston DA, Basore PA. PC1D VERSION 5- 32-BIT SOLAR CELL MODELING ON PERSONAL COMPUTERS. 26th IEEE Photovoltaics Spec Conf. 1997;207-10.

[15] Synopsis. Synopsys TCAD Now Offers Atomic-level Accuracy [Internet]. [cited 2018 Nov 23]. Available from: https://news.synopsys.com/index.php?s=20295\&item $=122584$

[16] Mouchart J. Thin film optical coatings. 1. Optical coating stabilities. Appl Opt [Internet]. 1977;16(9):2486-90. Available

from:

http://www.ncbi.nlm.nih.gov/pubmed/20168955 https://doi.org/10.1364/A0.16.002486

[17] Bouhafs D, Moussi A, Chikouche A, Ruiz JM. Design and simulation of antireflection coating for application to silicon solar cells. Sol Energy Mater Sol Cells. 1998;73(1):7993. https://doi.org/10.1016/S0927-0248(97)00273-0

[18] Al-turk S. Analytic Optimization Modeling of Anti-Reflection Coatings for Solar Cells Analytic Optimization Modeling of Anti-Reflection Coatings for Solar Cells. Matrix. 2011;

[19] Lecaruyer P, Maillart E, Canva M, Rolland J, Lecaruyer P, Maillart E, et al. Generalization of the Rouard method to an absorbing thin film stack and application to surface plasmon resonance To cite this version : HAL Id : hal-00664485 Generalization of the Rouard method to an absorbing thin-film stack and application to surface pl. Appl Opt Opt Soc Am. 2006;8419-23. https://doi.org/10.1364/A0.45.008419

[20] Chehura E, James SW, Tatam RP. Rouard's method as a modelling tool for the sensing characteristics of complex fibre Fabry-Perot interferometers formed between chirped 
fibre Bragg gratings . Proc SPIE. 2005;5855(May):338-41. https://doi.org/10.1117/12.623441

[21] Cronin TW, Marshall J. Patterns and properties of polarized light in air and water. Philos Trans R Soc B Biol Sci. 2011;366(1565):619-26. https://doi.org/10.1098/rstb.2010.0201

[22] Reithmeier M, Erbe A. Application of thin-film interference coatings in infrared reflection spectroscopy of organic samples in contact with thin metal films. Appl Opt [Internet]. 2011;50(9):C301. Available from: https://www.osapublishing.org/abstract.cfm?URI=ao-50-9-C301 https://doi.org/10.1364/A0.50.00C301

[23] Byrnes SJ. Multilayer optical calculations. 2016;1-20. Available from: http://arxiv.org/abs/1603.02720

[24] Mandong A. Design and simulation of single, double, and multi-layer antireflection coating for crystalline silicon solar cell [Internet]. Karadeniz Teknik Üniversitesi; 2019. Available from: http://acikerisim.ktu.edu.tr/jspui/handle/123456789/492

[25] Green MA. Self-consistent optical parameters of intrinsic silicon at $300 \mathrm{~K}$ including temperature coefficients. Sol Energy Mater Sol Cells. 2008;92(11):1305-10. https://doi.org/10.1016/i.solmat.2008.06.009

[26] Richards BS. Single-material TiO2double-layer antireflection coatings. Sol Energy Mater Sol Cells. 2003;79(3):369-90. https://doi.org/10.1016/S0927-0248(02)004737

[27] Dodge MJ. Refractive index of magnesium fluoride. Appl Opt. 1984;23(12):1980-5. https://doi.org/10.1364/A0.23.001980

[28] Siqueiros JM, Machorro R, Regalado LE. Determination of the optical constants of MgF2 and ZnS from spectrophotometric measurements and the classical oscillator method. Appl Opt. 1988;27(12):2549-53. https://doi.org/10.1364/A0.27.002549

[29] Baker-Finch SC, McIntosh KR. Reflection of normally incident light from silicon solar cells with pyramidal texture. Prog Photovoltaics Res Appl. 2016;19:406-16. https://doi.org/10.1002/pip.1050

[30] Polyanskiy MN. RefractiveIndex.INFO Database [Internet]. [cited 2018 Nov 22]. Available from: https://refractiveindex.info/cite.php

[31] Refractive index library [Internet]. [cited 2018 Nov 22]. Available from: https://www2.pvlighthouse.com.au/resources/photovoltaic materials/refractive index/refractive index.aspx

[32] Yang Z-P, Cheng H-E, Chang I-H, Yu I-S. Atomic Layer Deposition TiO2 Films and TiO2/SiNx Stacks Applied for Silicon Solar Cells. Appl Sci [Internet]. 2016;6(8):233. Available from: http://www.mdpi.com/2076-3417/6/8/233 https://doi.org/10.3390/app6080233

[33] Cid M, Stem N, Brunetti C, Beloto AF, Ramos CA. Improvements in anti-reflection coatings for high-efficiency silicon solar cells. Surf Coatings Technol. 1998;106(23):117-20. https://doi.org/10.1016/S0257-8972(98)00499-X

[34] Sharma R, Gupta A, Virdi A. Effect of single and double layer antireflection coating to enhance photovoltaic efficiency of silicon solar. J Nano- Electron Phys. 2017;9(2):4-7. https://doi.org/10.21272/inep.9(2).02001

[35] Ding K, Zhang X, Ning L, Shao Z, Xiao P, Ho-Baillie A, et al. Hue tunable, high color saturation and high-efficiency graphene/silicon heterojunction solar cells with MgF2/ZnS double anti-reflection layer. Nano Energy [Internet]. 2018;46(November 2017):257-65. https://doi.org/10.1016/j.nanoen.2018.02.005 